Review

\title{
A Systematic Review of the Cyclooxygenase-2 (COX-2) Expression in Rectal Cancer Patients Treated with Preoperative Radiotherapy or Radiochemotherapy
}

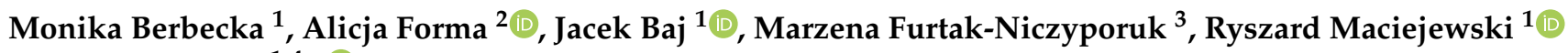 \\ and Robert Sitarz $1,4, *$ (D) \\ 1 Department of Normal Anatomy, Medical University of Lublin, 20-090 Lublin, Poland; \\ monikapilecka88@gmail.com (M.B.); jacek.baj@umlub.pl (J.B.); maciejewski.r@gmail.com (R.M.) \\ 2 Department of Forensic Medicine, Medical University of Lublin, 20-090 Lublin, Poland; aforma@onet.pl \\ 3 Department of Public Health, Medical University of Lublin, 20-954 Lublin, Poland; \\ marzenafurtakniczyporuk@umlub.pl \\ 4 Department of Surgical Oncology, St. John's Cancer Center, 20-090 Lublin, Poland \\ * Correspondence: r.sitarz@umlub.pl
}

check for

updates

Citation: Berbecka, M.; Forma, A.; Baj, J.; Furtak-Niczyporuk, M.;

Maciejewski, R.; Sitarz, R. A

Systematic Review of the

Cyclooxygenase-2 (COX-2)

Expression in Rectal Cancer Patients Treated with Preoperative

Radiotherapy or Radiochemotherapy. J. Clin. Med. 2021, 10, 4443. https:// doi.org/10.3390/jcm10194443

Academic Editor: Hidekazu Suzuki

Received: 12 August 2021

Accepted: 24 September 2021

Published: 27 September 2021

Publisher's Note: MDPI stays neutral with regard to jurisdictional claims in published maps and institutional affiliations.

Copyright: (C) 2021 by the authors Licensee MDPI, Basel, Switzerland. This article is an open access article distributed under the terms and conditions of the Creative Commons Attribution (CC BY) license (https:// creativecommons.org/licenses/by/ $4.0 /)$

\begin{abstract}
The main objective of this systematic review is to investigate the expression level of the cyclooxygenase-2 (COX-2) in rectal cancer treated with either preoperative radiotherapy or radiochemotherapy. In addition, we have summarized the effects of preoperative treatment of rectal cancer with regards to the expression levels of COX-2. A systematic literature review was performed in The Cochrane Library, PubMed, Web of Science, and Scopus databases on 1 January 2021 with the usage of the following search string-(cyclooxygenase-2) OR (COX-2) AND (rectal cancer) AND (preoperative radiochemotherapy) OR (preoperative radiotherapy). Among the 176 included in the analysis, only 13 studies were included for data extraction with a total number of 2095 patients. The results of the analysis are based on the articles concerning the expression of COX-2 in rectal cancer among patients treated with preoperative radiotherapy or radiochemotherapy. A COX-2 expression is an early event involved in rectal cancer development. In cases of negative COX-2 expression, radiotherapy and radiochemotherapy might contribute to the reduction of a local recurrence. Therefore, COX-2 may be considered as a biologic factor while selecting patients for more effective, less time-consuming and less expensive preoperative treatment. However, the utility of the administration of COX-2 inhibitors to patients with COX-2 overexpression, in an attempt to improve the patients' response rate to the neoadjuvant treatment, needs an assessment in further clinical trials.
\end{abstract}

Keywords: rectal adenocarcinoma; rectal cancer; cyclooxygenase-2; COX-2; radiotherapy; chemoradiotherapy

\section{Introduction}

In the last decades, a key enzyme in prostaglandin synthesis, cyclooxygenase-2 (COX-2), has been considered to play a key role in cancer development and progression [1,2]. Discussion of the COX-2 role in the prediction of response to the preoperative radiotherapy or chemoradiotherapy in rectal cancer requires knowledge of biochemistry and molecular effects of enzymatic activity, as well as an evaluation of the relationship between COX-2 expression and response to ionizing radiation. However, a detailed analysis of prostaglandin biology and mechanisms of interactions is beyond the scope of this review.

Cyclooxygenase (COX) regulates a key step in prostanoid synthesis. COX catalyzes the conversion of membrane phospholipids fraction-arachidonic acid (AA) - into an unstable prostaglandin $\mathrm{H} 2$ (PGH2) [3]. This initiates the prostaglandin synthesis trial, which is essential for inflammatory reactions, gastro-intestinal protection, homeostasis and renal hemodynamics. There are two principal isoforms of the COX-the 'constitutive' isoform 
COX-1 and 'inducible' isoform COX-2 [4]. These two COX isoforms present a similar catalytic activity; however, they are expressed in slightly different conditions-COX-1 is normal for homeostasis while COX-2 is induced in stress conditions (e.g., in response to injury, exposure to various endotoxins, mitogens and cytokines) and is significantly overexpressed at inflammation sites [5]. Except for the above-mentioned isoforms, a third isoform has been identified-COX-3, which is primarily expressed in the central nervous system and is considered to play a role in the induction of fever and pain processes [6]. According to the old dogma, COX-1 is mainly responsible for the synthesis of the prostaglandins involved in tissue homeostasis, while COX-2 is involved in their production under pathological conditions in particular. In addition, COX-2 is involved in a vast number of cellular processes, including gene expression, cellular differentiation, apoptosis, mitogenesis or neoplasia. COX-2 might be undetectable or present in low quantities in most of the tissues since it is primarily upregulated during inflammation; moreover, its expression might be significantly overexpressed in various cancerous tissues confirming its role in the induction and progression of a wide spectrum of pathological events during inflammation or dysregulated homeostasis $[7,8]$. The overexpression of COX-2 and COX-2 mRNA is not limited just to colon cancer but can be considered as a common feature in many solid tumors (head and neck squamous cell carcinomas, mesothelioma, hepatocellular carcinoma, gastric cancer, breast cancer and non-small cell lung carcinoma) [9-14]. Growth factors, such as epidermal growth factor (EGF), platelet-derived growth factor (PDGF), pro-inflammatory cytokines, tumor necrosis factor (TNF), tumor promoters, bile acids and ultraviolet $B$ irradiation, are involved in the stimulation of COX-2 expression.

A huge emphasis on the role of COX-2 in carcinogenesis was primarily made since the early 1990s when the first epidemiological reports regarding the effectiveness of the regular non-steroidal anti-inflammatory drugs (NSAIDs) in the prevention of colorectal cancer have appeared. It was established that COX-2 promotes pro-tumorigenic activity by several mechanisms, including angiogenesis development and resistance to apoptosis, modulation of host immune surveillance, increased DNA mutagenesis, activated peroxidase activity and xenobiotic carcinogens, which are all involved in the cancer invasiveness [15-18]. During AA metabolism by COX, also called prostaglandin $\mathrm{H}$ (PGH) synthase, several chemicals are metabolized. Sometimes, as a result of chemical metabolism, reactive metabolites of mutagenic and potentially carcinogenic activities can also be created. In addition, the peroxidase activity of COX can convert procarcinogens into carcinogens that are active in the tumor formation, as well as stimulate the conversion of the co-oxidized xenobiotics into mutagens. Several compounds that are obtained during the oxidation of the AA (malondialdehyde) can even form the adducts with the DNA. The demonstrated ability of the COX enzymes to activate environmental carcinogens as well as the pathways of aromatic and heterocyclic amines and polycyclic hydrocarbons is crucial in carcinogenesis.

So far, there are numerous reports describing tumorigenesis induced by the overexpression of COX-2. Liu et al. have observed an intensified COX-2 expression in the epithelial cells of the mammary glands, which was associated with a higher risk of hyperplasia and carcinomatosis [19]. One of the characteristics of colorectal cancer is the excessively high amount of the COX-2 protein or COX mRNA compared to the surrounding non-cancerous mucosa [20-22]. As a result, the expression of COX-2 is elevated in up to $90 \%$ of colorectal cancers. It has been proved that COX-2 expression is increased in adenoma and carcinoma; the COX-2 expression is higher in larger tumors and deep invasions, but the expression was not reported to be related neither to the tumor stage nor the metastasis. Nevertheless, it was shown that COX-2 expression correlates with tumor grade and stage, overall survival, as well as extent of the angiogenesis [23-28].

Recently, a wide range of different phenotypes and molecules (K-ras, p53, EGFR, microsatellite instability) have been studied as potential biological markers and prognostic factors of colorectal cancer. However, data regarding their association with the survival rate of colorectal cancer patients remains slightly inconsistent either considering those factors as insignificant [29-31] or contrarily, proving their relevance [32-35]. The latest 
research proves that increased COX-2 expression is an early event involved in rectal cancer development; evidence from practical and clinical studies indicates that COX-2-derived prostaglandins play an essential role in inflammation, immune response suppression, apoptosis inhibition, angiogenesis, tumor cell invasion, and metastasis [36-38].

Preoperative radiotherapy or chemoradiotherapy followed by a complete tumor resection are both well-established treatment strategies for locally advanced rectal cancer [39-41]. Moreover, the preoperative treatment seems to be also a well-suited model to evaluate biological factors. Therefore, several studies that investigated the relationship between COX-2 expression to radiotherapy/chemoradiotherapy and clinicopathologic variables in rectal cancer patients treated with preoperative radio- and chemoradiotherapy were conducted. It was shown that COX-2 inhibition (either by genetic or pharmacological means) might be effective in the inhibition of tumorigenic processes; moreover, several animal and human models showed that NSAIDs and coxibs might be useful in preventing the experimental colon cancer model [42-45]. Rahman et al. suggested that the usage of COX-2 inhibitors in selected groups of colorectal cancer patients (especially those with significantly upregulated COX-2 and MDR-1 levels) might result in significantly greater tumor regression and greater therapeutic response [46]. The need for more studies regarding the expression of COX-2 in different phases of carcinogenesis is emphasized to develop newer drugs that could potentially inhibit the COX-2 action, leading to greater prevention and therapeutic outcomes $[47,48]$.

In this systematic review, we aim to evaluate whether COX-2 expression might act as a prognostic/predictive factor for overall survival after neoadjuvant radio(chemo)therapy in rectal cancer and whether COX-2 inhibitors might act as additional drugs except for standard therapy. In addition, this paper aims to establish the guidelines for rectal cancer treatment regarding COX-2 expression levels and determine the utility of the assessment of COX-2 expression while predicting the treatment response in patients with rectal cancer who are undergoing preoperative radiotherapy or chemoradiotherapy.

\section{Guidelines for the Colorectal Cancer Treatment}

Colorectal cancer is currently the second leading cause of cancer-related deaths and the third most prevalently diagnosed cancer, according to GLOBOCAN 2020 data [49]. The highest prevalence of colorectal cancer is mainly observed in Europe, New Zealand, Australia and North America [50]. The risk of colorectal cancer increases with age (median age is about 70 years) but other risk factors such as genetic predisposition, improper diet (dietary components deficiencies, consumption of red and processed meat), smoking, inactive lifestyle, precancerous lesions, or other concomitant disorders (diabetes type II, colitis, Crohn's disease, or hereditary disorders-Lynch syndrome, familial adenomatous polyposis) should also be taken into consideration. Interestingly, NSAIDs intake is considered to be a protective factor against colorectal cancer incidence [51].

Currently, surgery remains the main treatment strategy of rectal cancer with radiation and chemotherapy provided either before or after the surgery. Early rectal cancers and most of the polyps can be removed during a colonoscopy by polypectomy or local excision. More complex types of surgery for rectal cancer include the transanal excision (TAE), transanal endoscopic microsurgery (TEM), low anterior resection (LAR), proctectomy with coloanal anastomosis, abdominoperineal resection (APR), diverting colostomy, or pelvic exenteration. When rectal cancer metastasizes, ablation or embolization might be useful. For rectal cancers, radiation therapy is commonly applied in form of neoadjuvant treatment or intraoperative treatment therapy (IORT). Further, chemotherapy might be provided at different stages of rectal cancer treatment; the most common drugs currently used include 5-fluorouracil, irinotecan, capecitabine, oxaliplatin, and trifluridine and tipiracil [52-56]. Regarding immunotherapy for colorectal cancer, PD-1 inhibitors-pembrolizumab and nivolumab, as well as CTLA-4 inhibitor, ipilimumab-are one of the most prevalently used [57-59]. 
In the last three decades, numerous therapeutic strategies for rectal cancer have evolved. At first, two landmark studies—-the National Surgical Adjuvant Breast and Bowel Protocol RO1 trial and the Gastrointestinal Tumor Study Group Protocol 7175 trial—proved the benefits of the adjuvant chemoradiation therapy for local control and long-term survival for patients with advanced carcinoma $[60,61]$. Several subsequent prospective randomized trials have demonstrated a decrease in a local recurrence and improvement in overall survival as an effect of colorectal cancer neoadjuvant therapy. Currently, preoperative radiotherapy or neoadjuvant chemoradiotherapy (CRT) followed by a complete tumor resection (total mesorectal excision-TME) constitutes a well-established treatment strategy for locally advanced rectal cancer.

Preoperative radiotherapy followed by TME reduces local recurrence rates and is recommended in intermediate cases (cT2, cT3 without threatened factors, some cT4a). In locally advanced, sometimes in non-resectable colorectal cancer cases, preoperative chemoradiotherapy followed by radical surgery even up to 12 weeks later should be provided. Neoadjuvant chemoradiation therapy is considered as a standard treatment aiming to reduce the local recurrence of cancer as well as to improve the marginal overall survival; however, its duration as well as type depends on the recommendations that slightly differ between countries (Table 1) [62,63].

Table 1. Preoperative therapies most prevalently provided in Europe, United States and Canada.

\begin{tabular}{cl}
\hline Region & \multicolumn{1}{c}{ Preoperative Therapy Description } \\
\hline Europe & $\begin{array}{l}\text { A short-course radiotherapy-1 week of radiation without chemotherapy (5 Gy } \times 5) \\
\text { followed by surgery the next week (TME }<10 \text { days from the first radiation fraction. }\end{array}$ \\
\hline United States and Canada & $\begin{array}{l}\text { A long-course chemoradiotherapy-45-50.4 Gy, 1.8-2 Gy/fraction without or with } \\
\text { 5-Fluorouracil (5-FU; bolus injections with leucovorin at 6-10 times during the radiation or } \\
\text { continuous infusion or oral capecitabine), followed by radical surgery 6-8 weeks later }\end{array}$ \\
\hline
\end{tabular}

Notwithstanding the benefits, the outcome of patients is still poor with a 5-year disease-free survival estimated at only $66 \%$; therefore, there is an urgent need for further improvements. The main therapeutic problems include the choice of the best standard of preoperative treatment, as well as tumor resistance (especially radio-resistance).

Currently, the main clinical objective is to search for the potential predictors that could identify those patients who would be the most vulnerable to preoperative treatment. The research is focused on the identification of molecular differences between the pre-treatment tumor biopsies of either responders or 'non-responders' to treatment. If a prediction of a patient's response to radiochemotherapy or radiotherapy was possible (in the early phase of treatment), the 'non-responders' (radio-resistant) might be selected for the alternative treatment, which aims at improving their response.

\section{Patients and Methods}

A systematic search of the PubMed, Cochrane, Web of Science and Scopus electronic databases was performed on 1 January 2021 with the usage of the following search string(cyclooxygenase-2) OR (COX-2) AND (rectal cancer) AND (preoperative radiochemotherapy) OR (radiochemotherapy) OR (preoperative radiotherapy) OR (radiotherapy). The above-mentioned terms were chosen in accordance with the Medical Subject Headings. An additional free search term has limited the results only to the articles related to the colorectal cancer. Terms were combined with Boolean operators. A non-mesh search was also performed. The final analysis included studies of any design that were specifically investigating the COX-2 expression assessment in prediction of response for treating rectal cancer with preoperative radiotherapy or chemoradiotherapy. The language of the articles was limited to English while there were no restrictions regarding the year of the publication. All of the analyzed articles were published and peer-reviewed and included only adult patients; the pre-prints were not taken into consideration. The articles with less 
than 27 patients in a study group as well as the case studies were excluded from the final analysis. Eventually, 13 articles were included in a qualitative synthesis with a time range 2005-2020.

\subsection{Assessment of Methodological Quality}

The methodological quality of the included studies was assessed by M.B. and A.F. All studies were graded according to the EBLIP critical appraisal checklist developed by Glynn L that takes into consideration such variables as study population, data collection, study design, as well as results [64]. An overall validity calculation of $\geq 75 \%$ indicates that the study can be considered as important. Title, abstract and full-text articles of all potentially relevant studies were screened for relevance by two independent (M.B. and A.F.) researchers. Reference lists and all of the articles found on the PubMed, Cochrane, Web of Science and Scopus databases were screened by M.B. and A.F. to ensure that no relevant studies were missed. Discrepancies were discussed and in case of any doubt, they have been resolved through the discussion with a third author-R.S. Preferred Reporting Items for Systematic Reviews and Meta-Analyses (PRISMA) guidelines were followed. Data were arranged in tabular form and qualitatively reviewed.

\subsection{Outcome Measures}

The papers included in the final analysis were analyzed in terms of the relationship between COX-2 expression and the effects of rectal cancer treatment while applying radiotherapy or radiochemotherapy.

\section{Results}

The search revealed 176 articles; after duplicates were removed, 48 articles were screened while 38 of them were assessed for eligibility. The analyzed articles included only those that concerned the studies performed on humans. The time range of the analyzed articles was 2005-2020. Two major inclusion criteria were the expression of COX-2 and either preoperative radiotherapy or preoperative radiochemotherapy applied in rectal cancer patients. Figure 1 depicts the PRISMA flow diagram for study selection. Table 2 depicts general study characteristics.

The search revealed 38 unduplicated articles, among which all of them have undergone a detailed assessment for eligibility providing a total number of 13 articles included in the final analysis. The analysis is based on all of the articles published as full article research (without limitation to language; even though, all of the articles were in English) investigating among others the expression of COX-2 in rectal cancer treated with preoperative radiotherapy or radiochemotherapy. The articles with less than 27 patients were not taken into consideration. No case reports were finally included, six articles were retrospective analyses of COX-2 expression in pretreatment biopsy (paraffin blocks) compared to post-treatment/post-irradiation of COX-2 expression.

The presented systematic review investigated a total of 2095 patients. The studies included in a final analysis were published between 2005 and 2020 and all of them were analyzing the significance of COX-2 expression in either preoperative radiotherapy or radiochemotherapy of rectal cancer, predicting the response of given treatment. In all of the studies, immunohistochemistry was used for COX-2 expression staining. The preparation for quantification of COX-2 was typical - paraffin-embedded tissue from pre-treatment biopsy was prepared and sectioned; then the membrane was blocked and incubated with primary antibodies against COX-2; afterwards, incubation with secondary antibody and detection reagent was performed. In some of the studies, apart from the COX-2 expression, the expression of other molecular markers was performed (p53, p21, p27, Bax, BCL-2, VEGF, APAF-1, CD34, Ki-67, VEGFR-2, EGFR, thymidine phosphorylase and others), which indicates the need for a further search of treatment predictors, including the molecular markers that are involved in cell growth, as well as in the prostanoid and apoptotic pathways [65-74]. 


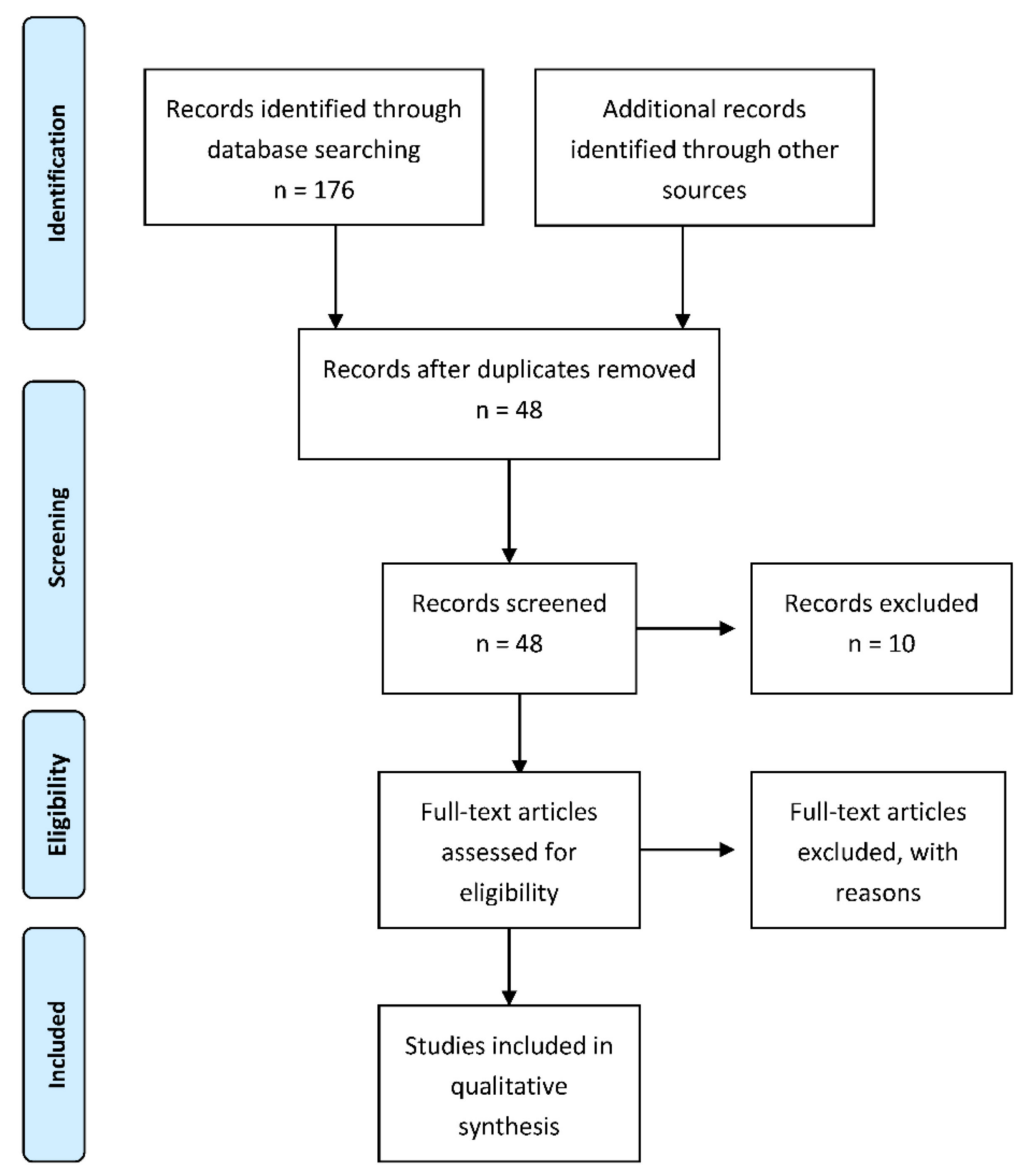

Figure 1. PRISMA flow diagram.

The majority of the tumors (94\%) expressed COX-2 only to some degree. COX-2 expression was mainly observed within the cancerous area. Within the tumor cells, the most common immunohistochemical staining pattern of COX-2 was brown, diffuse, granular, cytoplasmic staining. COX-2 expression was also proved to be increased in primary tumors compared with the non-cancerous mucosa $(p<0.0001)$, but no difference was observed between primary tumors and metastases. Heer et al. also investigated the COX-2 expression in relation to apoptosis with similar results-COX-2 expression in nonirradiated surgical specimens was negatively correlated with the apoptosis $(p=0.05-0.13)$; however, it was significantly associated with the decreased level of apoptosis in irradiated tumors $(p=0.001)$ [75]. COX-2 overexpression after radiotherapy was associated with apoptosis resistance and lower levels of radiotherapy-induced apoptosis. It is known that COX-2 induces Bcl-2 (anti-apoptotic protein family) expression, which suppresses radiationinduced cell death, which suggests the COX-2 tumorigenic activity. In Tables 2 and 3 , study characteristics are presented, while Table 4 provides information about the patients' characteristics. 
Table 2. Characteristics of the studies regarding COX-2 expression amongst patients with rectal cancer treated with preoperative radiotherapy.

\begin{tabular}{|c|c|c|c|c|c|c|c|c|}
\hline Ref. & Study & Year & Country & Study Design & Analyzed Samples & $\begin{array}{l}\text { Total Number of } \\
\text { Patients }\end{array}$ & Treatment Strategy & $\begin{array}{c}\text { COX-2 } \\
\text { Expression } \\
\text { Measurement }\end{array}$ \\
\hline [76] & Pachkoria et al. & 2005 & Sweden & $\begin{array}{l}\text { Prospective } \\
\text { randomized trial of } \\
\text { preoperative } \\
\text { radiotherapy }\end{array}$ & $\begin{array}{l}\text { Samples: } \\
\text { - distal normal mucosa }(n=28) \\
\text { - adjacent normal mucosa }(n=108) \\
\text { - primary cancer }(n=138) \\
\text { - lymph node metastasis }(n=30) \\
\text { - biopsy }(n=85)\end{array}$ & $\begin{array}{c}75 \\
\text { (138-total } \\
\text { 75-RTH + surgery } \\
\text { 63-surgery alone) }\end{array}$ & $\begin{array}{c}\text { Short-term radiation } \\
\text { (radiotherapy } 5 \times 5 \text { Gy to total } \\
\text { dose of } 25 \mathrm{~Gy} \text { ) followed } \\
\text { by surgery }\end{array}$ & $\begin{array}{c}\text { IHC } \\
\text { Western Blott }\end{array}$ \\
\hline [75] & de Heer et al. & 2007 & Netherlands & $\begin{array}{l}\text { Retrospective } \\
\text { multicenter } \\
\text { randomized } \\
\text { clinical trial }\end{array}$ & Archival tumor material & $\begin{array}{c}1038 \\
(924-\mathrm{RTH}+\text { surgery } \\
\text { 927-surgery alone) }\end{array}$ & $\begin{array}{c}\text { Short-term radiation } \\
\text { (radiotherapy } 5 \times 5 \text { Gy to total } \\
\text { dose of } 25 \text { Gy) followed by } \\
\text { TME surgery }\end{array}$ & IHC \\
\hline [77] & Giralt et al. & 2007 & Spain & Retrospective study & Preirridation diagnostic biopsies & $\begin{array}{c}34 \\
\text { (81-total } \\
\text { 34-radiotherapy } \\
47 \text { - } \\
\text { radiochemotherapy) }\end{array}$ & $\begin{array}{c}\text { Long-term radiation } \\
\text { (radiotherapy: conventional } \\
\text { fractionation } 1.8 \mathrm{~Gy} / \text { day to a } \\
\text { total dose of } 45 \mathrm{~Gy} \text {; additionally, } \\
\text { boost to } 50.4 \mathrm{~Gy} \text { in } 8 \text { cases) } \\
\text { followed by TME surgery }\end{array}$ & IHC \\
\hline [78] & Bouzourene et al. & 2008 & Switzerland & $\begin{array}{l}\text { Retrospective } \\
\text { multicenter } \\
\text { cohort study }\end{array}$ & $\begin{array}{l}\text { Pretherapeutic tumor biopsies } \\
(n=26) \text { and surgical specimens } \\
(n=88)\end{array}$ & $\begin{array}{c}104 \\
\text { (88 specimens } \\
26 \text { pretherapeutic } \\
\text { biopsies) }\end{array}$ & $\begin{array}{c}\text { Hyperfractionated } \\
\text { radiotherapy (HART) followed } \\
\text { by surgery } \\
\text { (APR or low anterior resection) }\end{array}$ & IHC \\
\hline [79] & Wen et al. & 2020 & Sweden & $\begin{array}{l}\text { Randomized } \\
\text { clinical trial }\end{array}$ & Surgical samples & $\begin{array}{c}219 \\
(127-\mathrm{RTH}+\text { surgery } \\
\text { 92-surgery alone })\end{array}$ & $\begin{array}{c}\text { Radiotherapy } \\
\text { (25 Gy in } 5 \text { fractions during a } \\
\text { median of } 6 \text { days (range, } 5-12) \text { ) } \\
\text { followed by surgery }\end{array}$ & IHC \\
\hline
\end{tabular}


Table 3. Cyclooxygenase-2 (COX-2) expression in rectal cancer treated with preoperative radiochemotherapy. Study characteristics.

\begin{tabular}{|c|c|c|c|c|c|c|c|c|c|}
\hline Ref. & Study & Year & Country & Study Design & Analyzed Samples & Total Number of Patients & & Treatment Strategy & $\begin{array}{c}\text { COX-2 } \\
\text { Expression } \\
\text { Measurement }\end{array}$ \\
\hline [80] & Yeoh et al. & 2005 & Australia & $\begin{array}{l}\text { Retrospective } \\
\text { study }\end{array}$ & $\begin{array}{l}\text { Samples obtained } \\
\text { from patiets treated } \\
\text { with preoperative } \\
\text { radiotherapy }\end{array}$ & 28 & $\begin{array}{l}(1) \\
\text { or } \\
(2) \\
(3)\end{array}$ & $\begin{array}{l}\text { Radiotherapy ( } 1.8 \text { Gy / day to total } 45 \text { Gy; boost } \\
5.4 \text { Gy) } \\
\text { Chemotherapy ( } 5 \text {-FU at } 300 \mathrm{mg} / \mathrm{m}^{2} / \text { day) }\end{array}$ & $\mathrm{IHC}$ \\
\hline [81] & Smith et al. & 2006 & Ireland & $\begin{array}{l}\text { Retrospective and } \\
\text { prospective study }\end{array}$ & $\begin{array}{l}\text { Pretreatment } \\
\text { specimens }\end{array}$ & 49 & $\begin{array}{l}(1) \\
(2) \\
(3)\end{array}$ & $\begin{array}{l}\text { Radiotherapy (to total dose of } 45 \text { Gy) } \\
\text { Chemotherapy ( } 5 \text {-FU at } 225 \mathrm{mg} / \mathrm{m}^{2} / \text { day) } \\
\text { Surgery }\end{array}$ & $\mathrm{IHC}$ \\
\hline [77] & Giralt et al. & 2007 & Spain & $\begin{array}{l}\text { Retrospective } \\
\text { study }\end{array}$ & $\begin{array}{c}\text { Preirridation } \\
\text { diagnostic biopsies }\end{array}$ & $\begin{array}{c}47 \\
(81 \text { - total } \\
\text { 34-radiotherapy } \\
47 \text {-radiochemotherapy) }\end{array}$ & $\begin{array}{l}(1) \\
(2) \\
(3)\end{array}$ & $\begin{array}{l}\text { Radiotherapy (1.8 Gy/day-conventional } \\
\text { fractionation to a total dose of } 45 \text { Gy; additionally, } \\
\text { boost to } 50.4 \text { Gy in } 8 \text { cases) } \\
\text { Simultaneous chemotherapy (5-FU) } \\
\text { Surgery-TME }\end{array}$ & $\mathrm{IHC}$ \\
\hline [82] & Min et al. & 2008 & Korea & Prospective study & $\begin{array}{l}\text { Pretreatment biopsy } \\
\text { specimens }\end{array}$ & 30 & $\begin{array}{l}(1) \\
(2)\end{array}$ & $\begin{array}{l}\text { Radiotherapy (to total dose of } 50.4 \text { Gy in } \\
25 \text { fractions) } \\
\text { Chemotherapy (5-FU at } 425 \mathrm{mg} / \mathrm{m}^{2} / \text { day and } \\
\text { Leucovorin } 20 \mathrm{mg} / \mathrm{m}^{2} / \text { day during first and fifth } \\
\text { week of radiotherapy) }\end{array}$ & $\mathrm{IHC}$ \\
\hline [83] & Edden et al. & 2010 & USA & $\begin{array}{l}\text { Retrospective } \\
\text { study }\end{array}$ & $\begin{array}{l}\text { Preatrement and } \\
\text { surgical specimens }\end{array}$ & 152 & $\begin{array}{l}(1) \\
(2) \\
(3)\end{array}$ & $\begin{array}{l}\text { Radiotherapy (to total dose of } 45 \mathrm{~Gy} \text {; boost to } \\
50.4 \mathrm{~Gy} \text { ); } \\
\text { Chemotherapy administrated with radiotherapy } \\
\left(5-\mathrm{FU} \text { at } 225 \mathrm{mg} / \mathrm{m}^{2} / \text { day or Capecitabine } 825 \mathrm{mg}\right. \\
2 \times / \text { day) } \\
\text { Surgery-TME }\end{array}$ & $\mathrm{IHC}$ \\
\hline
\end{tabular}


Table 3. Cont.

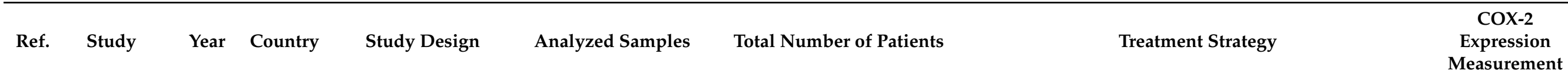

(1) Radiotherapy (50 Gy to the rectum as clinical tumor volume, CTV1 and 46 Gy to the region of pelvic lymph node as tumor volume CTV2; in 1.8-2.0 Gy/fraction over a period of 5 weeks

(2) Chemotherapy-concurrent with RTH one of two regimens: (1) FOLFOX (fluorouracil $3.0 \mathrm{~g} / \mathrm{m}^{2}$, CIV lasting for $48 \mathrm{~h}$; calcium folinate

[84] Peng et al. 2016 China $\begin{gathered}\text { Retrospective } \\ \text { study }\end{gathered}$ Pretreatment biopsies

82

$200.0 \mathrm{mg} / \mathrm{m}^{2}$, day 1 ; oxaliplatin $100.0 \mathrm{mg} / \mathrm{m}^{2}$ day 1 -repeated for 3 weeks ( $n=6$ patients, $7.3 \%$ )); (2) XELOX (capecitabine $1000.0 \mathrm{mg} / \mathrm{m}^{2}$ bid, days 1-14; oxaliplatin $100.0 \mathrm{mg} / \mathrm{m}^{2}$, day 1 -repeated for 3 weeks ( $n=76$ patients, $92.7 \%$ )

(3) Surgery

(4) Postoperative adjuvant chemotherapy (XELOX or FOLFOX)

(1) Radiotherapy-dose of 4500-5040 cGy in 25-28 fractions concurrent with Capecitabine (Xeloda) $825-850 \mathrm{mg} / \mathrm{m}^{2}$ dose twice daily

[85] Jafarian et al. 2016 Iran Retrospective Pretreatment cohort study specimens
55 and surgical specimens endoscopic biopsy

38

[86] Sole et al. 2016 Spain Prospective study
Measurement

(2) Mesorectal resection after 4-6 weeks of

neoadjuvant treatment

(3) Adjuvant chemotherapy (FOLFOX 4) for 6 months

(1) Neoadjuvant chemotherapy (oxaliplatin $85 \mathrm{mg} / \mathrm{m}^{2}$ on day 1 , leucovorin $200 \mathrm{mg} / \mathrm{m}^{2}$ on days 1 and 2,5-fluorouracil $400 \mathrm{mg} / \mathrm{m}^{2}$ on days 1 and 2 -over 2 weeks for 2 cycles (FLOFOX-4)

(2) Chemoradiotherapy (radiotherapy for 5-6 weeks to a cumulative dose of 45-50.4 Gy (1.8 Gy daily fractions) combined with oral chemotherapy (tegafur at $1200 \mathrm{mg}$ on days 1-4 and 21-25)

(3) Surgery 
Table 3. Cont.

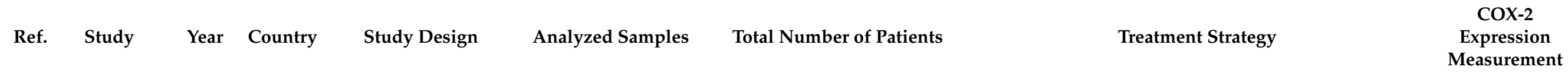

In the retrospective study:

(1) Short term radiation (to total dose of $20 \mathrm{~Gy}$

(5 daily doses of 4 Gy))

(2) Chemotherapy (tegafur-uracil at $400 \mathrm{mg} /$ day for

7 days throughout the period of irradiation)

(3) Surgery

[87] Shinto et al $2020 \quad$ Japan Retrospective and

prospective study
Pretreatment biopsies

144

95 in the

retrospective study 49 in the prospective study)
In the prospective study:

(1) Long term radiation (to total dose of $45 \mathrm{~Gy}$ (25 daily doses of $1.8 \mathrm{~Gy}$ )

(2) Chemotherapy (S-1 at $80 \mathrm{mg} /$ day (BSA below $1.25 \mathrm{~m}^{2}$ ), $100 \mathrm{mg} /$ day (BSA 1.25 to less than $1.5 \mathrm{~m}^{2}$ ), $120 \mathrm{mg} /$ day (BSA $1.5 \mathrm{~m}^{2}$ or above) and irinotecan at $80 \mathrm{mg} / \mathrm{m}^{2}$ ) 
Table 4. Patients characteristics in the studied articles.

\begin{tabular}{lcccccc}
\hline Ref. & Study & Total Number of Patients & Male & Female & Median Age & Age Range \\
\hline$[75]$ & de Heer et al. & $\begin{array}{c}1038(924-\text { RTH + surgery, } \\
927-\text { surgery alone) }\end{array}$ & 573 & 324 & 65 & $26-88$ \\
\hline$[78]$ & Bouzourene et al. & 104 & ND & ND & 63 & $28-85$ \\
\hline$[76]$ & Pachkoria et al. & 75 & 40 & 23 & 67 & $36-85$ \\
\hline$[81]$ & Smith et al. & 49 & 31 & 18 & ND & ND \\
\hline$[77]$ & Giralt et al. & 81 & 54 & 27 & 64.8 & $34-92$ \\
\hline$[83]$ & Edden et al. & 152 & 77 & 75 & 58.1 & $31-82$ \\
\hline$[80]$ & Yeoh et al. & 28 & 21 & 7 & ND & ND \\
\hline$[82]$ & Min et al. & 30 & 26 & 4 & 48.0 & $31-69$ \\
\hline$[87]$ & Shinto et al. & 144 & 100 & 44 & 61.8 & ND \\
\hline$[79]$ & Wen et al. & $219(127-R T H+$ surgery, & ND & ND & ND & ND \\
\hline$[84]$ & Peng et al. & $92-$ surgery alone $)$ & 57 & 25 & 57 & $15-75$ \\
\hline$[86]$ & Sole et al. & 38 & 27 & 11 & 62 & $43-77$ \\
\hline$[85]$ & Jafarian et al. & 55 & 27 & 18 & 52 & $18-87$
\end{tabular}

Only the research by de Heer et al. has found a significant association $(p=0.06)$ between the COX-2 expression and grading; a poor grade of differentiation was associated with high COX-2 expression levels in pretreatment specimens; a high level of COX-2 expression was more often observed both in irradiated and non-irradiated adenocarcinomas [75]. Shinto et al. also proved that low expression of COX-2 was an independent parameter that influenced tumor regression grade (TRG) [87]. According to the results of $75 \%$ of the analyzed studies, there is no significant correlation between COX-2 staining and age, gender, tumor downstaging, $\mathrm{pT}, \mathrm{pN}$, vascular invasion, tumor necrosis, Duke's stage, number of tumors and further complications. A relationship of the COX-2 expression in relation to the effects of treatment has been widely measured in numerous articles.

Firstly, weak COX-2 expression was associated with the lower rate of local recurrence after radiation in a study by Pachkoria et al. $(p=0.02)$; Heer et al. proved a correlation with a significantly higher rate of distant recurrences $(p=0.005)$ but not with the local recurrence $[75,76]$. Wen et al. also showed that patients with high expression of COX2 were more prone to suffer from tumor recurrence [79]. The possible explanation of COX-2 correlated recurrence is the ability to alternate in the invasive and metastatic potential of cancer cells. Induction of excessive prostaglandin production awakes cell surface glycosyltransferases and type 1 sialyl Lewis antigens, leading to the enhanced tumor cell adhesion to the endothelial cells. An increased prostaglandin production has an immunosuppressive effect, which promotes cells' escape from the host antitumor response and metastasis [88]. COX-2 is an immediate-early response gene [89]. Secondly, research conducted by Heer et al., shows that tumors with high levels of COX-2 expression after radiotherapy are significantly associated with poor disease-free survival $(p=0.004)$ as well as poor overall survival $(p=0.006)$ [75]. In addition, Bouzourene has shown that disease-free survival (DFS) is longer in patients who are radiosensitive compared to non-responders $(p=0.03)$ [78]. Wen et al. also proved that the patients with high COX-2 expression levels in biopsy samples tended to have worse OS and DFS, with or without RTH [79]. Moreover, Min, Smith, Edden and Jafarian et al. emphasize in their studies that COX-2 overexpression in pretreatment biopsies was found to be associated with a poor response to treatment $(p=0.003, p=0.026, p<0.031, p<0.001)[81-83,85]$. Peng et al. also showed that COX-2 expression was an independent risk factor for the pCR after RCT [84]. Additionally, independent prognostic factors for the overall survival are age above the median, advanced pathological stage, tumor-positive resection margins and COX-2 expression. A correlation between COX-2 expression and preoperative treatment effects, as well as clinical prognosis, are demonstrated in Tables 5-7. 
Table 5. Patients characteristics in the studied articles.

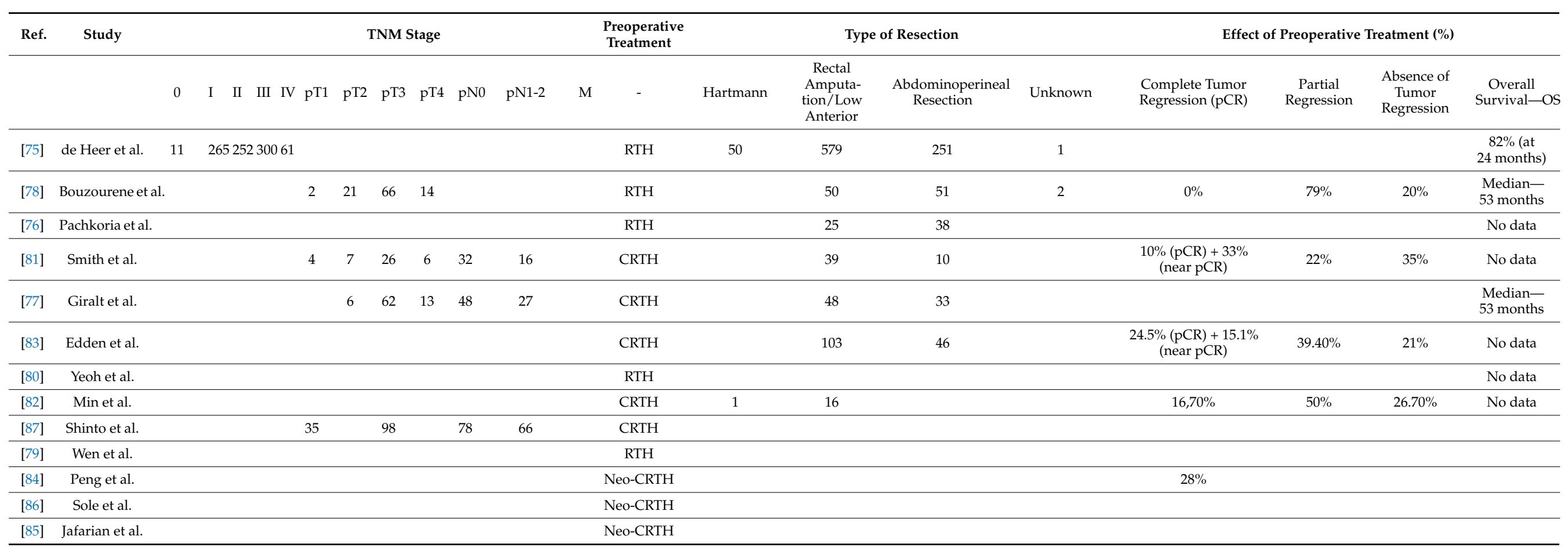


Table 6. COX-2 expression levels studies in the investigated articles.

\begin{tabular}{|c|c|c|c|}
\hline Ref. & Study & \multicolumn{2}{|c|}{ COX-2 Expression Level } \\
\hline \multirow{5}{*}{ [75] } & \multirow{5}{*}{ De Heer et al. (2015) } & \multicolumn{2}{|c|}{ Irradiated Specimens: } \\
\hline & & Absent & $0.4 \%$ \\
\hline & & Weak & $12.4 \%$ \\
\hline & & Moderate & $59.2 \%$ \\
\hline & & Strong & $28 \%$ \\
\hline \multirow{10}{*}{ [78] } & \multirow{10}{*}{ Bouzourene et al. (2008) } & \multicolumn{2}{|c|}{ Non-irradiated specimens: } \\
\hline & & Absent & $50 \%$ \\
\hline & & Weak & $15.4 \%$ \\
\hline & & Moderate & $15.4 \%$ \\
\hline & & Strong & $19.2 \%$ \\
\hline & & \multicolumn{2}{|c|}{ Irradiated specimens: } \\
\hline & & Absent & $11 \%$ \\
\hline & & Weak & $44 \%$ \\
\hline & & Moderate & $28 \%$ \\
\hline & & Strong & $17 \%$ \\
\hline \multirow{6}{*}{ [76] } & \multirow{6}{*}{ Pachkoria et al. (2005) } & \multicolumn{2}{|c|}{ Non-irradiated specimens: } \\
\hline & & Weak & $22 \%$ \\
\hline & & Strong & $51 \%$ \\
\hline & & \multicolumn{2}{|c|}{ Irradiated specimens: } \\
\hline & & Weak & $18 \%$ \\
\hline & & Strong & $53 \%$ \\
\hline [82] & Min et al. (2008) & & \\
\hline \multirow{5}{*}{ [81] } & \multirow{5}{*}{ Smith et al. (2006) } & COX-2 overexpression & $\begin{array}{c}\text { Tumor regression } \\
\text { grade }\end{array}$ \\
\hline & & $0 \%$ & Complete \\
\hline & & $10 \%$ & Moderate \\
\hline & & $8 \%$ & Poor \\
\hline & & $20 \%$ & Absent \\
\hline \multirow{3}{*}[77]{} & \multirow{3}{*}{ Giralt et al. (2007) } & \multicolumn{2}{|c|}{ Irradiated specimens: } \\
\hline & & Absent & $48.6 \%$ \\
\hline & & Present & $51.4 \%$ \\
\hline \multirow{4}{*}{ [83] } & \multirow{4}{*}{ Edden et al. (2010) } & \multicolumn{2}{|c|}{ Pretreatment biopsies: } \\
\hline & & Weak & $32.9 \%$ \\
\hline & & Moderate & $34.9 \%$ \\
\hline & & Strong & $32.2 \%$ \\
\hline [80] & Yeoh et al. (2005) & \multicolumn{2}{|c|}{ ND } \\
\hline \multirow{7}{*}{ [87] } & \multirow{7}{*}{ Shinto et al. (2020) } & \multicolumn{2}{|c|}{ Irradiated specimens: } \\
\hline & & \multicolumn{2}{|c|}{ Retrospective cohort: } \\
\hline & & Low & $21.1 \%$ \\
\hline & & High & $78.9 \%$ \\
\hline & & \multicolumn{2}{|c|}{ Prospective cohort: } \\
\hline & & Low & $30.6 \%$ \\
\hline & & High & $69.4 \%$ \\
\hline
\end{tabular}


Table 6. Cont.

\begin{tabular}{|c|c|c|c|}
\hline Ref. & Study & \multicolumn{2}{|c|}{ COX-2 Expression Level } \\
\hline \multirow{6}{*}{ [79] } & \multirow{6}{*}{ Wen et al. (2020) } & \multicolumn{2}{|c|}{ Non-irradiated specimens: } \\
\hline & & Absent & $67.7 \%$ \\
\hline & & Present & $32.3 \%$ \\
\hline & & \multicolumn{2}{|c|}{ Irradiated specimens: } \\
\hline & & Absent & $52.2 \%$ \\
\hline & & Present & $47.8 \%$ \\
\hline \multirow{3}{*}[84]{} & \multirow{3}{*}{ Peng et al. (2016) } & \multicolumn{2}{|c|}{ Irradiated specimens: } \\
\hline & & Low & $58.5 \%$ \\
\hline & & High & $41.5 \%$ \\
\hline [86] & Sole et al. (2016) & \multicolumn{2}{|c|}{ ND } \\
\hline [85] & Jafarian et al. (2016) & \multicolumn{2}{|c|}{$\begin{array}{l}\text { COX-2 expression was observed in } 95.6 \% \text { of cases } \\
\text { with various extent and intensities. }\end{array}$} \\
\hline
\end{tabular}

Table 7. Correlation between COX-2 expression and preoperative treatment effects and clinical prognosis.

\begin{tabular}{ccll}
\hline & & \multicolumn{2}{l}{ COX-2 Expression versus Tumor Prognosis: } \\
Ref. & COX-2 Expression versus & - & OS \\
& Treatment Effects & - & DFS \\
& & - & Local/Distant Recurrence
\end{tabular}

High COX-2 expression is an independent poor prognostic factor for disease-free and overall survival in irradiated rectal cancer patients
(1) Significantly higher rate of distant recurrences $(p=0.005)$ in tumors with high levels of COX-2 expression after radiotherapy

(2) In non-irradiated rectal cancer, COX-2 expression does not affect the local recurrence $(p=0.44)$, distant recurrences $(p=0.77)$, OS $(p=0.61)$ and DFS $(p=0.57)$

(3) In irradiated rectal cancer high levels of COX-2 expression associated with poor DFS $(p=0.004)$, poor OS $(p=0.006)$

(4) COX-2 expression significantly associated with decreased levels of apoptosis in irradiated tumors $(p=0.001)$

(1) No significant correlation between the expression level of COX-2 and OS after radiotherapy but longer DFS among radiosensitive patients

(1) Inconclusive data

(2) COX-2 is overexpressed

[78]

Bouzourene et al. (2008)

in the majority of rectal cancer treated with radiotherapy and it plays a role in local relapse

COX-2 expression is an early

[76] Pachkoria et al. (2005) event involved in rectal cancer development
(2) High levels of COX-2 expression after radiotherapy associated with local recurrences

(3) COX-2 expression correlates with enhanced tumor inflammation $(p=0.03)$ and tumor volume exceeding $30 \mathrm{cc}$ $(p=0.05)$

(4) No correlation between COX-2 expression and clinicopathological features (gender, age, Duke's stage, TNM, tumor regression)

(1) Weak COX-2 expression before and after radiotherapy is related to a lower rate of local recurrence $(p=0.02)$

(2) Radiotherapy may reduce local recurrence in cases with negative COX-2 expression

(3) COX-2 expression elevated in primary tumors compared to normal mucosa; no difference between primary tumors and metastases $(p=0.38)$

(4) Duke's stage not related to the effects of radiotherapy 
Table 7. Cont.

\begin{tabular}{ccll}
\hline & & \multicolumn{2}{l}{ COX-2 Expression versus Tumor Prognosis: } \\
Ref. & COX-2 Expression versus & - & OS \\
& Treatment Effects & - & DFS \\
& & - & Local/Distant Recurrence \\
\hline
\end{tabular}

[82] Min et al. (2008) $\quad \begin{aligned} & \text { COX-2 overexpression is a } \\ & \text { predictor of poor tumor } \\ & \text { regression }\end{aligned}$

COX-2 overexpression

[81] Smith et al. (2006) significantly associated with poor response to RCT

(1) COX-2 expression correlated more likely with poor response to treatment $(p=0.003)$

(2) In COX-2 overexpression tumors less histopathologic nodal downstaging $(p=0.03)$

(3) Any of patient with COX-2 overexpression attained complete regression of primary tumor after treatment

(4) Pretreatment biopsies with COX-2 overexpression demonstrate moderate or poor response to treatment $(p=0.026)$

(5) Low level of spontaneous apoptosis in pretreatment biopsies is associated with worse response to radiation $(p=0.0007)$

(1) No significant correlation between the expression level of COX-2 and OS and DFS after radiochemotherapy

[77] Giralt et al. (2007) biomarker is controversial

(2) No correlation between COX-2 expression and clinicopathological features (gender, age, Duke's stage, number of tumors)

(3) COX-2 expression does not predict treatment response

Evaluation of pretreatment COX-2 expression may

[83] Edden et al. (2010) predict tumor response to neoadjuvant rectal cancer therapy
(1) COX-2 overexpression in pretreatment biopsies is related to poor tumor regression $(p<0.003)$ and less likelihood of T-downstaging $(p<0.03)$ after radiochemotherapy

(1) No apparent difference in COX-2 expression between short-term radiation and long-term chemoradiation therapy
[80] Yeoh et al. (2005)

[87] Shinto et al. (2020)

[84] Peng et al. (2016)
The expression of COX-2 was significant predictor of tumour response to preoperative RCT. However, expression levels of COX-2 showed no statistical significance.

The expression of COX-2 had diagnostic value for rectal cancer patients preoperatively (the expression in biopsy sample was higher than that in surgical samples including distance normal mucosa (histologically free from tumor cells), $p<0.05$ )

Low expression of COX-2 was associated with achieving the highest $\mathrm{pCR}$ rate, which was significantly higher than those with high expression of COX-2.
(1) Low expression of COX-2 was independent or marginally independent parameter that influenced tumor regression grade (TRG).

(2) TRG 3-4 was associated with positive IHC findings for reduced expression of COX-2 $(p<0.001)$.

(1) The patients with high COX-2 expression level in biopsy samples tended to have worse OS ( $p=0.044$ with RTH) and DFS, with or without radiotherapy.

(2) Positive expression of COX-2 (RTH $(p=0.022)$ and nonRTH $(p=0.084)$ had reduced DFS time compared to those with negative tumors.

(3) The expression of COX-2-RTH $(p<0.001)$ was independent prognostic factor for local/distance recurrence. Patients with high expression of COX-2 were more prone to suffer from tumor recurrence.

(1) COX-2 expression was independent risk factor for $\mathrm{pCR}$ after neo-RCT. 
Table 7. Cont.

\begin{tabular}{|c|c|c|c|c|}
\hline \multirow[b]{2}{*}{ Ref. } & \multirow[b]{2}{*}{ Study } & \multirow[b]{2}{*}{$\begin{array}{l}\text { COX-2 Expression versus } \\
\text { Treatment Effects }\end{array}$} & \multicolumn{2}{|r|}{ COX-2 Expression versus Tumor Prognosis: } \\
\hline & & & $\begin{array}{l}- \\
-\end{array}$ & $\begin{array}{l}\text { OS } \\
\text { DFS } \\
\text { Local/Distant Recurrence }\end{array}$ \\
\hline [86] & Sole et al. (2016) & $\begin{array}{l}\text { No significant differences in } \\
\text { COX-2 expression level. }\end{array}$ & (1) & No significant differences in COX-2 expression level. \\
\hline [85] & Jafarian et al. (2016) & $\begin{array}{l}\text { The mean COX- } 2 \\
\text { immunoreactivity extent in } \\
\text { pre-RCT samples was } \\
\text { significantly higher in cases } \\
\text { with post-RCT biopsies } \\
\text { showing }>50 \% \text { necrosis than } \\
\text { those with }<50 \% \text { necrosis } \\
(p<0.01)\end{array}$ & (1) & $\begin{array}{l}\text { Patients with good response to neoadjuvant therapy did not } \\
\text { show extensive COX-2 staining extent in pretreatment } \\
\text { specimens. } 90 \% \text { of poor responders revealed extensive COX-2 } \\
\text { staining extent }(p<0.001)\end{array}$ \\
\hline
\end{tabular}

Abbreviations: RTH—radiotherapy, RCT—radiochemotherapy, OS—overall survival, DFS—disease free survival.

\section{Discussion}

During the last decades, therapeutic strategies for rectal cancer treatment have significantly evolved. The initial step that aimed to change the treatment guidelines regarding rectal cancer were two trials conducted by the National Surgical Adjuvant Breast and Bowel Protocol RO1 and Gastrointestinal Tumor Study Group Protocol 7175, which have established the beneficial impact of adjuvant radiation and chemoradiation therapy for local control and long-term survival. These results were confirmed by several subsequent prospective randomized trials.

The most important attribute of radio/radiochemotherapy is the ability to induce a complete pathological response, which equals the complete absence of tumor in surgical specimens. Despite the huge role of adjuvant treatment in decreasing local recurrence and improving overall survival, the results of treatment are varying from complete response to little or even no response. Usually, only $15-30 \%$ of patients show a favorable response to treatment with the usage of $\mathrm{pCR}$. Thus, to quantify tumor response for neoadjuvant therapy, several techniques as well as numerous researches investigating different molecular mechanisms and molecules have been provided. In order to reduce a variation in tumor response, neoadjuvant regimens were also standardized. A significant number of patients have their surgical intervention delayed and those are unnecessarily exposed to the toxic effects of rectal cancer treatment that is usually ineffective, time-, and cost-consuming. The response to the combined neoadjuvant therapy predicts the final outcome. The clue task is to discover specific biomarkers or provide a method that could be potentially useful to differentiate the tumor 'responders' from the 'non-responders'. The most important disadvantage of the neoadjuvant treatment is the fact that patients with a worse response cannot be identified until the time of pathologic analysis; all in all, the 'non-responders' (radio-resistance) are not selected for alternative treatment, which can improve their response. What is crucial is the histopathological assessment; however, imaging studies should also be provided in the case of rectal cancer-an MRI performed after radiotherapy aims to assess patients' response to treatment and further qualification for potential surgery. At present, no means of predicting treatment response exists and all patients must undergo empirical preoperative treatment and surgery. Preoperative treatment is a well-suited model to evaluate and compare the expression of the biological factors (biomarkers are analyzed in the diagnostic biopsy and in the tumor specimen after treatment, correlation with an outcome). Currently, available therapeutic strategies are fundamentally based on the $\mathrm{T}$ and $\mathrm{N}$ stages and often do not consider a tumor's biological genotype and phenotype [90,91]. This practice might result in either over-treatment or under-treatment. There is a need to identify a molecular biomarker that could be measured before preoperative treatment, allowing to 
divide patients into specific subgroups. Based on the observation that long-term use of a COX-2 inhibitor (rofecoxib) can reduce rectal polyp formation in patients with familial adenosis polyposis, COX-2 inhibitors are currently widely investigated [92,93]. Short-term usage of COX-2 inhibitors combined with preoperative radiochemotherapy turned out to be safe and effective for patients with locally advanced rectal cancer; however, more research in this matter is still needed [94]. The selective COX-2 inhibitor, used with radiation, can significantly increase tumor susceptibility to radiation by inhibiting the release of prostaglandins [95]. The first results of combined treatment with COX-2 inhibitor and neoadjuvant treatment are promising; efficacy and good toleration of celecoxib (COX-2 selective inhibitor) administration were observed [96,97].

This systematic review investigated a total of 2095 patients. The studies included in a final analysis were published between 2005 and 2020 and were focused on the analysis of the significance of COX-2 expression in rectal cancer preoperative radiotherapy or radiochemotherapy by predicting the response of given treatment. $80 \%$ of the studies were based on the retrospective analysis of COX-2 expression in pretreatment biopsy (paraffin blocks) compared to post-treatment/post-irradiation COX-2 expression. In each case, immunohistochemistry was used for COX-2 expression staining. In some of the studies, apart from COX-2 expression, the expression of other molecular markers was also investigated (p53, p21, p27, Bax, BCL-2, VEGF, APAF-1, CD34, Ki-67, VEGFR-2, EGFR, thymidine phosphorylase and others), which indicates the need of searching for other treatment predictors among molecular markers involved in cell growth, as well as in the prostanoid and apoptotic pathways. All of the presented methods of treatment were administrated according to the individual staging (TNM, Dukes's classification) and in accordance with the ruling guidelines for rectal cancer treatment.

It should be considered that our study has some limitations that are mainly the consequences of the available literature. Although the systematic search was performed in The Cochrane Library, PubMed, Web of Science, and Scopus databases, only 13 researches were found. Each of the analyzed studies had a similar methodology but the study groups were not easy to collate due to the lack of important data (overall survival or summary of preoperative treatment) or lack of expression of COX-2 measurement details. Another difficulty was a standardization of given preoperative treatment-in four cases, preoperative radiotherapy was provided (in three research short-term radiotherapy-5 $55 \mathrm{~Gy}$, one research-long-term) and in four cases radiochemotherapy was administrated preoperatively. Some of the results seem to be inconclusive, probably due to the small study population. Further, it should be considered that COX-2 expression is slightly different interpreted amongst studies; the interpretation whether its expression was high or low was primarily based on the results of the ones studies rather than reference values, which de facto remain not constant as previously mentioned. Another limitation is the fact that the stages in which the samples were collected remained different between studies and further were sometimes not clearly defined by the authors.

Based on the systematic review, apart from investigating the role of COX-2 expression in neoadjuvant rectal cancer treatment response, we have proposed a novel pretreatment proceeding in rectal cancer, which is based on the well-established guidelines for rectal cancer treatment and the most recent research regarding the COX-2 inhibition during preoperative treatment (Diagram 1). Since it was observed that the increase of COX-2 activity amongst colorectal cancer patients is associated with greater progression of carcinogenesis, it is suggested that COX-2 expression might act as a prognostic factor in some aspects [98]. Further, COX-2 overexpression might induce further angiogenesis, which is also attributed to poorer clinical outcome, presenting its significance in clinical practice [99].

To the best of our knowledge, there are no accessible studies that summarize the effects of rectal cancer preoperative treatment in relation to the levels of COX-2 expression, which makes the presented study a novel review. Nevertheless, to confirm our results and validate the predictive power of COX-2 as a diagnostic marker, further additional independent research is needed. 


\section{Conclusions}

A COX-2 expression is an early event involved in rectal cancer development. In cases with negative COX-2 expression, radiotherapy and radiochemotherapy may reduce the local recurrence. Taking those facts into consideration, COX-2 may be considered as a biological factor in selecting patients for more effective, less time-, and cost-consuming preoperative treatment. Administration of COX-2 inhibitors to patients with COX-2 overexpression, in an attempt to improve the response rate to neoadjuvant treatment, needs an assessment in further clinical trials.

Author Contributions: Conceptualization, R.S. and R.M.; methodology, R.S. and M.B.; formal analysis, J.B., A.F. and M.F.-N.; investigation, M.B. and A.F.; data curation, A.F., J.B. and M.B.; writing—original draft preparation, M.B.; writing—review and editing, A.F., J.B., M.F.-N. and R.S.; supervision, R.S.; project administration, R.M.; funding acquisition, R.M. All authors have read and agreed to the published version of the manuscript.

Funding: This research received no external funding.

Institutional Review Board Statement: Not applicable.

Informed Consent Statement: Not applicable.

Conflicts of Interest: The authors declare no conflict of interest.

\section{References}

1. Goradel, N.H.; Najafi, M.; Salehi, E.; Farhood, B.; Mortezaee, K. Cyclooxygenase-2 in cancer: A review. J. Cell. Physiol. 2019, 234, 5683-5699. [CrossRef] [PubMed]

2. Fujimura, T.; Ohta, T.; Oyama, K.; Miyashita, T.; Miwa, K. Role of cyclooxygenase-2 in the carcinogenesis of gastrointestinal tract cancers: A review and report of personal experience. World J. Gastroenterol. 2006, 12, 1336-1345. [CrossRef] [PubMed]

3. Simmons, D.L.; Botting, R.M.; Hla, T. Cyclooxygenase isozymes: The biology of prostaglandin synthesis and inhibition. Pharmacol. Rev. 2004, 56, 387-437. [CrossRef] [PubMed]

4. Fitzpatrick, F.A. Cyclooxygenase enzymes: Regulation and function. Curr. Pharm. Des. 2004, 10, 577-588. [CrossRef]

5. Jackson, L.M.; Wu, K.C.; Mahida, Y.R.; Jenkins, D.; Hawkey, C.J. Cyclooxygenase (COX) 1 and 2 in normal, inflamed, and ulcerated human gastric mucosa. Gut 2000, 47, 762-770. [CrossRef]

6. Davies, N.M.; Good, R.L.; Roupe, K.A.; Yáñez, J.A. Cyclooxygenase-3: Axiom, dogma, anomaly, enigma or splice error?-Not as easy as 1, 2, 3. J. Pharm. Pharm. Sci. 2004, 7, 217-226.

7. Liu, B.; Qu, L.; Yan, S. Cyclooxygenase-2 promotes tumor growth and suppresses tumor immunity. Cancer Cell Int. 2015, 15, 106. [CrossRef]

8. Stasinopoulos, I.; Shah, T.; Penet, M.-F.; Krishnamachary, B.; Bhujwalla, Z.M. COX-2 in cancer: Gordian knot or achilles heel? Front. Pharmacol. 2013, 4, 34. [CrossRef]

9. Saba, N.F.; Choi, M.; Muller, S.; Shin, H.J.C.; Tighiouart, M.; Papadimitrakopoulou, V.A.; El-Naggar, A.K.; Khuri, F.R.; Chen, Z.G.; Shin, D.M. Role of cyclooxygenase-2 in tumor progression and survival of head and neck squamous cell carcinoma. Cancer Prev. Res. 2009, 2, 823-829. [CrossRef]

10. Marrogi, A.; Pass, H.I.; Khan, M.; Metheny-Barlow, L.J.; Harris, C.C.; Gerwin, B.I. Human mesothelioma samples overexpress both cyclooxygenase-2 (COX-2) and inducible nitric oxide synthase (NOS2): In Vitro antiproliferative effects of a COX-2 inhib-itor. Cancer Res. 2000, 60, 3696-3700.

11. Cervello, M.; Montalto, G. Cyclooxygenases in hepatocellular carcinoma. World J. Gastroenterol. 2006, 12, 5113-5121. [CrossRef] [PubMed]

12. Hahm, K.-B.; Lim, H.-Y.; Sohn, S.; Kwon, H.-J.; Lee, K.-M.; Lee, J.-S.; Surh, Y.-J.; Kim, Y.-B.; Joo, H.-J.; Kim, W.-S.; et al. In Vitro evidence of the role of COX-2 in attenuating gastric inflammation and promoting gastric carcinogenesis. J. Environ. Pathol. Toxicol. Oncol. 2002, 21, 165-176. [CrossRef]

13. Harris, R.E.; Casto, B.C.; Harris, Z.M. Cyclooxygenase-2 and the inflammogenesis of breast cancer. World J. Clin. Oncol. 2014, 5, 677-692. [CrossRef]

14. Petkova, D.; Clelland, C.; Ronan, J.; Pang, L.; Coulson, J.; Lewis, S.; Knox, A. Overexpression of cyclooxygenase-2 in non-small cell lung cancer. Respir. Med. 2004, 98, 164-172. [CrossRef]

15. Crosby, C.G.; Dubois, R.N. The cyclooxygenase-2 pathway as a target for treatment or prevention of cancer. Expert Opin. Emerg. Drugs 2003, 8, 1-7. [CrossRef]

16. Yu, T.; Lao, X.; Zheng, H. Influencing COX-2 Activity by COX Related Pathways in Inflammation and Cancer. Mini Rev. Med. Chem. 2016, 16, 1230-1243. [CrossRef]

17. Bakhle, Y.S. COX-2 and cancer: A new approach to an old problem. Br. J. Pharmacol. 2001, 134, 1137-1150. [CrossRef] 
18. Greenhough, A.; Smartt, H.J.; Moore, A.E.; Roberts, H.R.; Williams, A.C.; Paraskeva, C.; Kaidi, A. The COX-2/PGE2 pathway: Key roles in the hallmarks of cancer and adaptation to the tumour microenvironment. Carcinogenesis 2009, 30, 377-386. [CrossRef]

19. Liu, C.H.; Chang, S.-H.; Narko, K.; Trifan, O.C.; Wu, M.-T.; Smith, E.; Haudenschild, C.; Lane, T.F.; Hla, T. Overexpression of Cyclooxygenase-2 is sufficient to induce tumorigenesis in transgenic mice. J. Biol. Chem. 2001, 276, 18563-18569. [CrossRef] [PubMed]

20. Sheng, J.; Sun, H.; Yu, F.-B.; Li, B.; Zhang, Y.; Zhu, Y.-T. The role of cyclooxygenase-2 in colorectal cancer. Int. J. Med. Sci. 2020, 17, 1095-1101. [CrossRef] [PubMed]

21. Wang, D.; DuBois, R.N. The role of COX-2 in intestinal inflammation and colorectal cancer. Oncogene 2009, 29, 781-788. [CrossRef]

22. Roelofs, H.M.; Morsche, R.H.T.; Van Heumen, B.W.; Nagengast, F.M.; Peters, W.H. Over-expression of COX-2 mRNA in colorectal cancer. BMC Gastroenterol. 2014, 14, 1. [CrossRef]

23. Soslow, R.A.; Dannenberg, A.J.; Rush, D.; Woerner, B.M.; Khan, K.N.; Masferrer, J.; Koki, A.T. COX-2 is expressed in human pulmonary, colonic, and mammary tumors. Cancer 2000, 89, 2637-2645. [CrossRef]

24. Zhang, H.; Sun, X.F. Overexpression of cyclooxygenase-2 correlates with advanced stages of colorectal cancer. Am. J. Gastroen-terol. 2002, 97, 1037-1041. [CrossRef] [PubMed]

25. Eberhart, C.E.; Coffrey, R.J.; Radhika, A.; Giardiello, F.M.; Ferrenbach, S.; DuBois, R.N. Up-regulation of cyclooxygenase 2 gene ex-pression in human colorectal adenomas and adenocarcinomas. Gastroenterology 1994, 107, 1183-1188. [CrossRef]

26. Masferrer, J.L.; Leahy, K.M.; Koki, A.T.; Zweifel, B.S.; Settle, S.L.; Woerner, B.M.; Edwards, D.A.; Flickinger, A.G.; Moore, R.J.; Seibert, K. Antiangiogenic and antitumor activities of cy-clooxygenase-2 inhibitors. Cancer Res. 2000, 60, 1306-1311. [PubMed]

27. Sheehan, K.M.; Sheahan, K.; O’Donoghue, D.P.; MacSweeney, F.; Conroy, R.M.; Fitzgerald, D.J.; Murray, F.E. The relationship between cy-clooxygenase-2 expression and colorectal cancer. JAMA 1999, 282, 1254-1257. [CrossRef] [PubMed]

28. Cianchi, F.; Cortesini, C.; Bechi, P.; Fantappie, O.; Messerini, L.; Vannacci, A.; Sardi, I.; Baroni, G.; Boddi, V.; Mazzanti, R.; et al. Upregulation of cyclooxygenase 2 gene expres-sion correlates with tumor angiogenesis in human colorectal cancer. Gastroenterology 2001, 121, 1339-1347. [CrossRef]

29. Markman, B.; Ramos, F.J.; Capdevila, J.; Tabernero, J. EGFR and KRAS in colorectal cancer. Adv. Virus Res. 2010, 51, 71-119. [CrossRef]

30. Nakayama, M.; Oshima, M. Mutant p53 in colon cancer. J. Mol. Cell Biol. 2019, 11, 267-276. [CrossRef]

31. Nojadeh, J.N.; Sharif, S.B.; Sakhinia, E. Microsatellite instability in colorectal cancer. EXCLI J. 2018, 17, 159-168. [CrossRef]

32. Dinu, D.; Dobre, M.; Panaitescu, E.; Bîrlă, R.; Iosif, C.; Hoara, P.; Caragui, A.; Boeriu, M.; Constantinoiu, S.; Ardeleanu, C. Prognostic significance of KRAS gene mutations in colorectal cancer-preliminary study. J. Med. Life 2015, 7, 581-587.

33. Wang, P.; Liang, J.; Wang, Z.; Hou, H.; Shi, L.; Zhou, Z. The prognostic value of p53 positive in colorectal cancer: A retrospective cohort study. Tumor Biol. 2017, 39. [CrossRef] [PubMed]

34. Huang, C.-W.; Chen, Y.-T.; Tsai, H.-L.; Yeh, Y.-S.; Su, W.-C.; Ma, C.-J.; Tsai, T.-N.; Wang, J.-Y. EGFR expression in patients with stage III colorectal cancer after adjuvant chemotherapy and on cancer cell function. Oncotarget 2017, 8, 114663-114676. [CrossRef]

35. Kang, S.; Na, Y.; Joung, S.Y.; Lee, S.I.; Oh, S.C.; Min, B.W. The significance of microsatellite instability in colorectal cancer after controlling for clinicopathological factors. Medicine 2018, 97, e0019. [CrossRef]

36. Kunzmann, A.T.; Murray, L.J.; Cardwell, C.; McShane, C.M.; McMenamin, Ú.; Cantwell, M.M. PTGS2 (cyclooxygenase-2) expression and survival among colorectal cancer patients: A systematic review. Cancer Epidemiol. Biomark. Prev. 2013, 22, 1490-1497. [CrossRef] [PubMed]

37. Su, C.-W.; Zhang, Y.; Zhu, Y.-T. Stromal COX-2 signaling are correlated with colorectal cancer: A review. Crit. Rev. Oncol. 2016, 107, 33-38. [CrossRef] [PubMed]

38. Negi, R.R.; Rana, S.V.; Gupta, V.; Gupta, R.; Chadha, V.D.; Prasad, K.K.; Dhawan, D.K. Over-expression of cyclooxygenase-2 in colorectal cancer patients. Asian Pac. J. Cancer Prev. 2019, 20, 1675-1681. [CrossRef] [PubMed]

39. Anania, G.; Resta, G.; Marino, S.; Fabbri, N.; Scagliarini, L.; Marchitelli, I.; Fiorica, F.; Cavallesco, G. Treatment of colorectal cancer: A multidisciplinary approach. J. Gastrointest. Cancer 2019, 50, 458-468. [CrossRef]

40. Xue, L.; Williamson, A.; Gaines, S.; Andolfi, C.; Paul-Olson, T.; Neerukonda, A.; Steinhagen, E.; Smith, R.; Cannon, L.; Polite, B.; et al. An update on colorectal cancer. Curr. Probl. Surg. 2018, 55, 76-116. [CrossRef]

41. Mirnezami, R.; Chang, G.J.; Das, P.; Chandrakumaran, K.; Tekkis, P.; Darzi, A.; Mirnezami, A.H. Intraoperative radiotherapy in colorectal cancer: Systematic review and meta-analysis of techniques, long-term outcomes, and complications. Surg. Oncol. 2013, 22, 22-35. [CrossRef] [PubMed]

42. Sinicrope, F.A. Targeting cyclooxygenase-2 for prevention and therapy of colorectal cancer. Mol. Carcinog. 2006, 45, 447-454. [CrossRef] [PubMed]

43. Sinicrope, F.A.; Gill, S. Role of cyclooxygenase-2 in colorectal cancer. Cancer Metastasis Rev. 2004, 23, 63-75. [CrossRef] [PubMed]

44. Moshkowitz, M.; Arber, N. Cyclo-oxygenase-2 inhibitors in colorectal cancer prevention. Am. J. Cancer 2006, 5, 357-362. [CrossRef]

45. Gonzalez-Angulo, A.M.; Fuloria, J.; Prakash, O. Cyclooxygenase 2 inhibitors and colon cancer. Ochsner J. 2002, 4, 176-179. [PubMed]

46. Rahman, M.; Selvarajan, K.; Hasan, M.R.; Chan, A.P.; Jin, C.; Kim, J.; Chan, S.K.; Le, N.D.; Kim, Y.-B.; Tai, I.T. Inhibition of COX-2 in colon cancer modulates tumor growth and MDR-1 expression to enhance tumor regression in therapy-refractory cancers In Vivo. Neoplasia 2012, 14, 624-IN18. [CrossRef] 
47. Hidalgo-Estévez, A.M.; Stamatakis, K.; Jiménez-Martínez, M.; López-Pérez, R.; Fresno, M. Cyclooxygenase 2-regulated genes an alternative avenue to the development of new therapeutic drugs for colorectal cancer. Front. Pharmacol. 2020, 11, $243-247$. [CrossRef] [PubMed]

48. Nasir, A.; Kaiser, H.E.; Boulware, D.; Hakam, A.; Zhao, H.; Yeatman, T.; Barthel, J.; Coppola, D. Cyclooxygenase-2 expression in right- and left-sided colon cancer: A rationale for optimization of cyclooxygenase-2 inhibitor therapy. Clin. Color. Cancer 2004, 3 , 243-247. [CrossRef] [PubMed]

49. Sung, H.; Ferlay, J.; Siegel, R.L.; Laversanne, M.; Soerjomataram, I.; Jemal, A.; Bray, F. Global cancer statistics 2020: Globocan estimates of incidence and mortality worldwide for 36 cancers in 185 countries. CA Cancer J. Clin. 2021, 71, 209-249. [CrossRef]

50. Fitzmaurice, C.; Abate, D.; Abbasi, N.; Abbastabar, H.; Abd-Allah, F.; Abdel-Rahman, O.; Abdelalim, A.; Abdoli, A.; Abdollahpour, I.; Abdulle, A.S.; et al. Global, regional, and national cancer incidence, mortality, years of life lost, years lived with disability, and disability-adjusted life-years for 29 cancer groups, 1990 to 2017: A systematic analysis for the global burden of disease study. JAMA Oncol. 2019, 5, 1749-1768.

51. Smalley, W.; Ray, W.A.; Daugherty, J.; Griffin, M.R. Use of nonsteroidal anti-inflammatory drugs and incidence of colorectal cancer. Arch. Intern. Med. 1999, 159, 161-166. [CrossRef] [PubMed]

52. Pardini, B.; Kumar, R.; Naccarati, A.; Novotny, J.; Prasad, R.; Forsti, A.; Hemminki, K.; Vodicka, P.; Bermejo, J.L. 5-Fluorouracilbased chemotherapy for colorectal cancer and MTHFR/MTRR genotypes. Br. J. Clin. Pharmacol. 2010, 72, 162-163. [CrossRef]

53. Fujita, K.-I.; Kubota, Y.; Ishida, H.; Sasaki, Y. Irinotecan, a key chemotherapeutic drug for metastatic colorectal cancer. World J. Gastroenterol. 2015, 21, 12234-12248. [CrossRef]

54. Zafar, S.Y.; Hirsch, B.R. Capecitabine in the management of colorectal cancer. Cancer Manag. Res. 2011, 3, 79-89. [CrossRef]

55. Comella, P. Role of oxaliplatin in the treatment of colorectal cancer. Ther. Clin. Risk Manag. 2009, 5, 229-238. [CrossRef] [PubMed]

56. Burness, C.B.; Duggan, S.T. Trifluridine/tipiracil: A review in metastatic colorectal cancer. Drugs 2016, 76, 1393-1402. [CrossRef]

57. Coupez, D.; Hulo, P.; Touchefeu, Y.; Bossard, C.; Bennouna, J. Pembrolizumab for the treatment of colorectal cancer. Expert Opin. Biol. Ther. 2020, 20, 219-226. [CrossRef] [PubMed]

58. Smith, K.M.; Desai, J. Nivolumab for the treatment of colorectal cancer. Expert Rev. Anticancer. Ther. 2018, 18, 611-618. [CrossRef]

59. Morse, M.A.; Overman, M.J.; Hartman, L.; Khoukaz, T.; Brutcher, E.; Lenz, H.; Atasoy, A.; Shangguan, T.; Zhao, H.; El-Rayes, B. Safety of nivolumab plus low-dose ipilimumab in previously treated microsatellite instability-high/mismatch repair-deficient metastatic colorectal cancer. Oncologist 2019, 24, 1453-1461. [CrossRef]

60. Wolmark, N.; Wieand, H.S.; Hyams, D.M.; Colangelo, L.; Dimitrov, N.V.; Romond, E.H.; Wexler, M.; Prager, D.; Cruz, A.B.; Gordon, P.H.; et al. Randomized trial of postoperative adjuvant chemotherapy with or without radiotherapy for carcinoma of the rectum: National surgical adjuvant breast and bowel project protocol R-02. J. Natl. Cancer Inst. 2000, 92, 388-396. [CrossRef]

61. Thomas, P.R.; Lindblad, A.S. Adjuvant postoperative radiotherapy and chemotherapy in rectal carcinoma: A review of the gastrointestinal tumor study group experience. Radiother. Oncol. 1988, 13, 245-252. [CrossRef]

62. Glimelius, B.; Tiret, E.; Cervantes, A.; Arnold, D. Rectal cancer: ESMO clinical practice guidelines for diagnosis, treatment and follow-up. Ann. Oncol. 2013, 24, vi81-vi88. [CrossRef]

63. Glimelius, B. Optimal time intervals between pre-operative radiotherapy or chemoradiotherapy and surgery in rectal cancer? Front. Oncol. 2014, 4, 50. [CrossRef]

64. Glynn, L. A critical appraisal tool for library and information research. Libr. Hi Tech 2006, 24, 387-399. [CrossRef]

65. Lim, S.-C.; Lee, T.-B.; Choi, C.-H.; Ryu, S.-Y.; Kim, K.-J.; Min, Y.-D. Expression of cyclooxygenase-2 and its relationship to p53 accumulation in colorectal cancers. Yonsei Med. J. 2007, 48, 495-501. [CrossRef]

66. Grösch, S.; Tegeder, I.; Niederberger, E.; Bräutigam, L.; Geisslinger, G. COX-2 independent induction of cell cycle arrest and apoptosis in colon cancer cells by the selective COX-2 inhibitor celecoxib. FASEB J. 2001, 15, 2742-2744. [CrossRef]

67. Sheng, H.; Shao, J.; Morrow, J.D.; Beauchamp, R.D.; Dubois, R.N. Modulation of apoptosis and Bcl-2 expression by prostaglandin E2 in human colon cancer cells. Cancer Res. 1998, 58, 9443418.

68. Xiong, B.; Sun, T.-J.; Yuan, H.-Y.; Hu, M.-B.; Hu, W.-D.; Cheng, F.-L. Cyclooxygenase-2 expression and angiogenesis in colorectal cancer. World J. Gastroenterol. 2003, 9, 1237-1240. [CrossRef] [PubMed]

69. Peng, H.; You, K.; Zhang, R.; Xi, S.; Zhang, T.; Dong, J.; Cai, M.; Wang, C.; Zhang, H.; Zhou, T.; et al. Predictive value of APAF-1 and COX-2 expression in pathologic complete response to neoadjuvant chemoradiotherapy for patients with locally advanced rectal adenocarcinoma. Oncotarget 2016, 7, 35233-35240. [CrossRef] [PubMed]

70. Masunaga, R.; Kohno, H.; Dhar, D.K.; Ohno, S.; Shibakita, M.; Kinugasa, S.; Yoshimura, H.; Tachibana, M.; Kubota, H.; Nagasue, N. Cyclooxygenase-2 expression correlates with tumor neovascularization and prognosis in human colorectal carcinoma patients. Clin. Cancer Res. 2000, 6, 4064-4068. [PubMed]

71. Sakuma, K.; Fujimori, T.; Hirabayashi, K.; Terano, A. Cyclooxygenase (COX)-2 immunoreactivity and relationship to p53 and Ki-67 expression in colorectal cancer. J. Gastroenterol. 1999, 34, 189-194. [CrossRef]

72. Chu, A.J.; Chou, T.H.; Chen, B.D. Prevention of colorectal cancer using COX-2 inhibitors: Basic science and clinical applications. Front. Biosci. 2004, 9, 2697-2713. [CrossRef]

73. Ceccarelli, C.; Piazzi, G.; Paterini, P.; Pantaleo, M.A.; Taffurelli, M.; Santini, D.; Martinelli, G.N.; Biasco, G. Concurrent EGFr and Cox-2 expression in colorectal cancer: Proliferation impact and tumour spreading. Ann. Oncol. 2005, 16, iv74-iv79. [CrossRef] 
74. Nakamoto, R.H.; Uetake, H.; Iida, S.; Kolev, Y.V.; Soumaoro, L.T.; Takagi, Y.; Yasuno, M.; Sugihara, K. Correlations between Cyclooxygenase-2 expression and angiogenic factors in primary tumors and liver metastases in colorectal cancer. Jpn. J. Clin. Oncol. 2007, 37, 679-685. [CrossRef] [PubMed]

75. Heer, P.D.; Gosens, M.J.; Bruin, E.C.D.; Dekker-Ensink, N.G.; Putter, H.; Marijnen, C.A.; van den Brule, A.J.; van Krieken, J.H.J.; Rutten, H.J.; Kuppen, P.J.; et al. Cyclooxygenase 2 expression in rectal cancer is of prognostic significance in patients receiving preoperative radiotherapy. Clin. Cancer Res. 2007, 13, 2955-2960. [CrossRef]

76. Pachkoria, K.; Zhang, H.; Adell, G.; Jarlsfelt, I.; Sun, X.-F. Significance of Cox-2 expression in rectal cancers with or without preoperative radiotherapy. Int. J. Radiat. Oncol. 2005, 63, 739-744. [CrossRef]

77. Giralt, J.; Navalpotro, B.; Hermosilla, E.; De Torres, I.; Espin, E.; Reyes, V.; Cerezo, L.; De Las Heras, M.; y Cajal, S.R.; Armengol, M. Prognostic significance of vascular endothelial growth factor and cyclooxygenase-2 in patients with rectal cancer treated with preoperative radiotherapy. Oncology 2006, 71, 312-319. [CrossRef]

78. Bouzourene, H.; Yan, P.; Sandmeier, D.; Zouhair, A.; Matter, M.; Vuilleumier, H.; Coucke, P. The role of COX-2 in rectal cancer treated with preoperative radiotherapy. Virchows Arch. 2008, 452, 499-505. [CrossRef]

79. Wen, Y.; Zhao, S.; Holmqvist, A.; Hahn-Stromberg, V.; Adell, G.; Holmlund, B.; Pathak, S.; Peng, Z.; Sun, X.F. Predictive role of biopsy based Bi-omarkers for radiotherapy treatment in rectal cancer. J. Pers. Med. 2020, 13, 168.

80. Yeoh, A.S.; Bowen, J.M.; Gibson, R.J.; Keefe, D.M. Nuclear factor кB (NFkB) and cyclooxygenase-2 (Cox-2) expression in the irradiated colorectum is associated with subsequent histopathological changes. Int. J. Radiat. Oncol. 2005, 63, 1295-1303. [CrossRef] [PubMed]

81. Smith, F.M.; Reynolds, J.V.; Kay, E.W.; Crotty, P.; Murphy, J.O.; Hollywood, D.; Gaffney, E.F.; Stephens, R.B.; Kennedy, M.J. COX-2 overexpression in pretreatment biopsies predicts response of rectal cancers to neoadjuvant radiochemotherapy. Int. J. Radiat. Oncol. 2006, 64, 466-472. [CrossRef]

82. Min, B.S.; Choi, Y.J.; Pyo, H.R.; Kim, N.-K.; Seong, J.; Chung, H.C.; Rha, S.Y. Cyclooxygenase-2 expression in pretreatment biopsy as a predictor of tumor responses after preoperative chemoradiation in rectal cancer. Arch. Surg. 2008, 143, 1091. [CrossRef]

83. Edden, Y.; Wexer, S.D.; Berhof, M. The use of molecular markers as a method to predict the response to neoadjuvant therapy for advanced stage rectal adenocarcinoma. Colorectal Dis. 2011, 14, 555-561. [CrossRef] [PubMed]

84. Zlobec, I.; Minoo, P.; Baker, K.; Haegert, D.; Khetani, K.; Tornillo, L.; Terracciano, L.; Jass, J.R.; Lugli, A. Loss of APAF-1 expression is associated with tumour progression and adverse prognosis in colorectal cancer. Eur. J. Cancer 2007, 43, 1101-1107. [CrossRef]

85. Kermani, A.T.; Jafarian, A.; Esmaeili, J.; Roshan, N.; Seilanian-Toosi, M.; Omidi, A.; Shahri, M.K. The role of COX-2 and Ki-67 over-expression in the prediction of pathologic response of rectal cancer to neoadjuvant chemoradiation therapy. Indian J. Cancer 2016, 53, 548-551. [CrossRef] [PubMed]

86. Sole, C.V.; Calvo, F.A.; Alvarez, E.; Carreras, J.L. Metabolic and molecular relative percentage coreduction in patients with locally advanced rectal cancer treated with neoadjuvant therapy. Eur. J. Nucl. Med. Mol. Imaging 2016, 43, 1444-1452. [CrossRef] [PubMed]

87. Shinto, E.; Omata, J.; Sikina, A.; Sekizawa, A.; Kajiwara, Y.; Hayashi, K.; Hashiguchi, Y.; Hase, K.; Ueno, H. Predictive immunohistochemical features for tumour response to chemoradiotherapy in rectal cancer. BJS Open 2020, 4, 301-309. [CrossRef]

88. Kalinski, P. Regulation of immune responses by prostaglandin E2. J. Immunol. 2011, 188, 21-28. [CrossRef] [PubMed]

89. Maier, J.A.; Hla, T.; Maciag, T. Cyclooxygenase is an immediate-early gene induced by interleukin-1 in human endothelial cells. J. Biol. Chem. 1990, 265, 10805-10808. [CrossRef]

90. Hueman, M.; Wang, H.; Henson, D.; Chen, D. Expanding the TNM for cancers of the colon and rectum using machine learning: A demonstration. ESMO Open 2019, 4, e000518. [CrossRef]

91. Diaconescu, M.; Burada, F. T4 colon cancer-current management. Curr. Health Sci. J. 2018, 44, 5-13. [CrossRef]

92. Hallak, A.; Alon-Baron, L.; Shamir, R.; Moshkowitz, M.; Bulvik, B.; Brazowski, E.; Halpern, Z.; Arber, N. Rofecoxib reduces polyp recurrence in familial polyposis. Dig. Dis. Sci. 2003, 48, 1998-2002. [CrossRef] [PubMed]

93. Kim, B.; Giardiello, F.M. Chemoprevention in familial adenomatous polyposis. Best Pr. Res. Clin. Gastroenterol. 2011, 25, 607-622. [CrossRef]

94. Wang, L.-W.; Hsiao, C.-F.; Chen, W.T.-L.; Lee, H.-H.; Lin, T.-C.; Chen, H.-C.; Chen, H.-H.; Chien, C.-R.; Lin, T.-Y.; Liu, T.-W. Celecoxib plus chemoradiotherapy for locally advanced rectal cancer: A phase II TCOG study. J. Surg. Oncol. 2014, 109, 580-585. [CrossRef]

95. Choy, H. Enhancing radiotherapy with cyclooxygenase-2 enzyme inhibitors: A rational advance? J. Natl. Cancer Inst. 2003, 95, 1440-1452. [CrossRef] [PubMed]

96. Ghosh, N.; Chaki, R.; Mandal, V.; Mandal, S.C. COX-2 as a target for cancer chemotherapy. Pharmacol. Rep. 2010, 62, 233-244. [CrossRef]

97. Li, S.; Jiang, M.; Wang, L.; Yu, S. Combined chemotherapy with cyclooxygenase-2 (COX-2) inhibitors in treating human cancers: Recent advancement. Biomed. Pharmacother. 2020, 129, 110389. [CrossRef] [PubMed]

98. Wu, Q.-B.; Sun, G.-P. Expression of COX-2 and HER-2 in colorectal cancer and their correlation. World J. Gastroenterol. 2015, 21, 6206-6214. [CrossRef] [PubMed]

99. Koehne, C.H.; Dubois, R.N. COX-2 inhibition and colorectal cancer. Semin Oncol. 2004, 31, 12-21. [CrossRef] [PubMed] 